\title{
Research: \\ THE EFFECT OF CORPORATE FINANCIAL RATIO UPON THE COMPANY VALUE
}

\author{
Kamilah Sadi’ah \\ Department of Accounting, Economic College of Binaniaga, Bogor, Indonesia \\ sadiahkamila@gmail.com (K. Sa'diah)
}

Received: September 12, 2018; Accepted: November 9, 2018; Published: December 31, 2018

To cite this article: Kamilah Sa'diah. The Effect of Corporate Financial Ratio upon The Company Value,

The Accounting Journal of BINANIAGA, Vol. 03, No. 02, December 2018, pp. 75-88. doi: 10.33062/ajb.v3i2.245

\begin{abstract}
This study aimed to get empirical evidence about the effect of corporate financial ratios consists of return on assets, dividend payout ratio and debt-to equity ratio on the firm value. Firm value uses a price-to book value (PBV) by calculating the price market per share divided by book value per share. Population of this research is the companies listed in LQ45 on the Indonesia Stock Exchange in 2015-2016 which some 45 companies using total sampling technique. Methods of data analysis using descriptive statistical analysis and multiple linear regression. These results indicate that corporate financial ratios consists of return on assets, dividend payout ratio and debt-to equity ratio have a significant effect simultaneously on the firm value. However, partial test results showed that return on assets and dividend payout ratio have a significat effect on the firm value. While the debt-to equity ratio has no significant effect on the firm value.
\end{abstract}

Key words: price-to book value, return on assets, dividend payout ratio, firm value.

\section{INTRODUCTION}

Shareholders are the people who are holding the highest authority in a limited corporation. Company performance can be measured by the reliable information stated on the financial report, which is the basic of decision making of investment, asset management and other finance resources (Elinda and Sukirman, 2015). Economic Community ASEAN, which has been running since 2015, and Indonesia is a country, which has joined and obliged to follow the directing blueprint to be implemented on the integrated economy in South East Asia. This circumstance is the moment to improve the value of the companies, specifically for the companies, which have been 'go public' to increase the owners or the shareholders' well-being. (Salvatore, mentioned on Hermuningsih, 2013).

Some factors that could influence the increasing of shareholders well-being thru the company's values are profitability, dividend policy and investment decision that can be analyzed or measured by the ratio of the company's finance. The company value can be measured based on the ratio or profitability level applying the measurement of Return on Assets (ROA), this ratio is quite famous being used by the financial analysts. ROA is the ability of the company gaining the profit after tax refers to marketing activities, company's size or financing structure. Company's profit is the most important thing to increase its shares' price in the bourse significantly. For example, fluctuated price of the shares of PT Garuda Tujuh Buana, Tbk (GTBO), PT Bumi Resources, Tbk (BUMI). PT Krakatau Steel, Tbk (KRAS), PT Bakrieland Development, Tbk (ELTY) and PT Garuda Indonesia, Tbk (Limited enterprise - GIAA) which are categorized within LQ45 enterprises, this condition has made the stock exchange agents think over placing their 
capital based on a certain portfolio (www.liputan6.com mentioned on Agustina Melani, 2014). Referring to the previous research done by Hermuningsih (2013), Mayogi and Fidiana (2016) have indicated the result is consistent which is the profitability applying ROA has been affecting the value of the company.

The company value is not only depending on the particular extent of return on assets (ROA) but also is being determined by the ratio of dividend payment or dividend payout ratio (DPR) There is an uncertain circumstance encountered by the companies to define the dividend payment for the companies which are applying the investment composition (Okpara, mentioned on Gayatri and Mustanda, 2013). The dividend payout policy of the company has been always facing the problems related to the agent and principal behavior. Referring to Pruitt and Gitman (1991, mentioned on Arshad et al, 2013), some factors influencing the dividend policy are (1) present and previous profit; (2) uncertainty of profit an profit evolvement; (3) dividend of the previous year; and (4) level of present profit, future profit, expected profit and pattern or dividend continuity of the previous year. All factors above has been mostly become the intention of the shareholders and investor about the return factor which is the reflection of the company value that is able to increase the well-being of shareholders. Some previous research of Wahyuningsing (2015), Mayogi and Fidiana (2016) have indicated consistent result about the dividend that has been formulated by thru dividend payout ratio (DPR) which has positively affected the company value.

Liability is the financing support coming from the external of the company. Liability policy is the strategy taken by the management of the company to get the financing resources to support the company operational cost. Advantage is one of the liability ratio being used to measure the power of company financial (DER) the companies having huge DER ratio will allocate a low dividend payout, which might be, violate the credit terms. (Utomo, 2016). The research of Hermuningsih (2013) indicated a consistent result which is the structure of capital using the measuring of debt-to-equity (DER) ratio having positive effect upon the company value, however the research of Wahyuningsih (2015) and Mayogi and Fidiana (2016) indicated that there is not any significant result over the credit policy using debt-to-equity (DER) ratio to identify the company value.

The investors to place their investment on the portfolio investment identify the companies listed on the Indonesia Stock Exchange and categorized in the LQ45 shares. Index LQ45 has had particular criteria of price to book value (P/BV) refers to the price of shares reflected in the value of company. Referring to Self Regulatory Organization (SRO) thru the Indonesia Stock Exchange (KBIE) and Indonesia Stocks Guarantee (KPEI), the product of periodical contract based on Stocks Index (KBIE), LQ45 Futures is reintroduced to cover the capital needs to increase the value of investment in the Indonesia Stock Exchange which has been vacuum since 2009 (www.finance.detik.com mentioned on Dina Rayanti, 2016). Therefore, the title of this research is named "The Effect of ROA, DPR and DER upon the Company Value". Objects of the research are the companies having LQ45 Index listed on the Indonesia Stock Exchange (BEI) year of 2015-2016".

\section{LITERATURE REVIEW}

\section{Agency Theory}

Agency theory is the theory based on the connection between the principal and the management (agent) introduced by Jensen and Meckling in 1976. Investors are the parties, which are connected with the company's ownership delegating the management to manage and to be responsible for their wealth, which is expected they can increase the investors' well-being and prosperity in line with the increasing of the company value. On the other hand, the management appointed as the agents by the principal is believed as the responsible people morally who can make optimum profit for the principals by receiving the compensations according to the contract. The value of a company is the 
perception of the investors upon the shares price, which can increase the market trustworthy upon the present company performance and prospect of the company (Hermuningsih, 2013). This mechanism is expected to be able to reduce the agency problems as the basic of evaluation and compensation given according to their job contract to increase the company value.

\section{Signaling Theory}

The manager is in charge of giving the signal about the condition of the company to the owner due to their responsibility to manage the company. Signaling theory has described that the company should have been providing the information of its financial report to the external parties. The increasing value of the company applying the mechanism of dividend policy is the signal that the related information can be distributed to the market instead of the theory of optimum dividend policy. Dividend information as the tool to send the actual signal to the market about the result of the present company performance and the expected performance which is the right way even though it is quite expensive but it is worth much more, because the higher dividend per share is indicating that the company believes that the future cash flow will be sufficient to cover the level of high dividend (Weston and Copeland, 2010). After receiving the signal from the dividend information, market will be responding the related information, however, it can be said that the market has understood that such an information is reflecting the prospect or the value of the company (Ambarwati, 2010)

\section{Return On Assets}

Return on Assets (ROA) is the percentage measurement to evaluate how good the company is able to gain the acceptable profit. ROA is one of the popular profitability ratio used by many researchers. The profitability is the ability of the company to gain the profit connected with the sales, total assets or the capital itself (Sartono, 2010). Furthermore, profitability ratio can be measured thru 2 (two) approaches, sales approach and investment approach. Return on Assets (ROA) and Return on Equity (ROE) are the measurements being used to describe business attraction.

Good profitability condition of company will attract the investors' intention to invest their capital in that company. Particularly, long-term investors are very concerned with the ratio of return on asset, for example, the shareholders will study about the level of assets returnable as the measurement to recognize the company performance and the price of its shares (Blaylock et al., 2012) This research has measured ratio of return on assets (ROA) since it has reflected the level of company operation efficiency to gain the profit using the equation as follows:

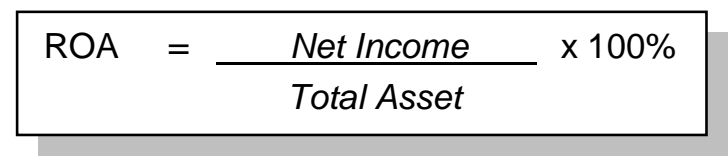

(Source: Subramanyam, 2014:450)

\section{Dividend Payout Ratio}

Dividend Payout Ratio (DPR) is one of the measurement being used to determine a decision created by the company about the profit allocation for the stockholders whether it can be distributed or reinvested for the future. Referring to Modigliani and Miller (1961, mentioned on Sartono: 2010), dividend payout ratio has not affected the price of company share or investment or it is irrelevant dividend. The value of company is determined by the earning power of the company's assets. Referring to Martono and Harjito (2008:253, in Wahyuningsih research, 2015), dividend policy is a decision made whether end-year profit of the company will be distributed to the shareholders or retained as the future investment. 
Having payout the dividend, it is expected that the company will be gaining a higher value for the investors. Nevertheless, paying-out the dividend continuously, the company is able to face the economical fluctuation and able to give the result to the shareholders accordingly. This research has measured the dividend payout ratio (DPR) by comparing dividend per share with earnings per share using the following equation:

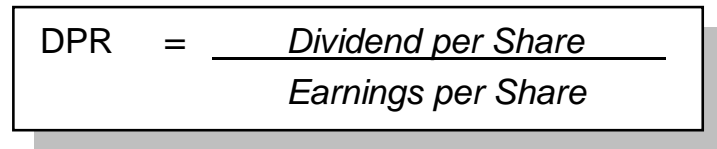

(Source: Brigham and Houston, 2013:69)

Dividend per share (DPS) can be calculated by dividing the total of dividend payout with the market shares, but earnings per share is calculated by comparing net profit after tax (EAT) with the total of market shares.

\section{Debt-to Equity Ratio}

Debt-to Equity Ratio (DER) is one of the measurement per unit to measure the amount of financing the liability in the capital structure of the company (Subramanyam, 2014:565). DER is solvability ratio, which is popular being used by many of the researches applying the leverage measurement. DER ratio is useful to identify the amount of the financing provided by the creditor to the owner of the company, which is having the function to recognize each rupiah of self-owned capital, which can guarantee the liability (Kashmir, 2012:158).

Profitable companies are the companies that are having bigger available earnings to be retained or invested, and they have tended to develop the equities comparing with the debt. Therefore, the lower the DER, the higher ability of the company to pay all its liabilities, and on the contrary, the bigger the liabilities proportion is applied for the capital structure of the company, the bigger liabilities will be (Ang. 2010).

This research has applied Debt-to Equity Ratio (DER), because DER has been reflecting the ability of the company business to settle down its long-term liabilities or all its liabilities if the related company is liquidated. The following leverage equation is as follows:

\begin{tabular}{|c|c|}
\hline \multirow{2}{*}{$\begin{array}{c}\text { Debt to Equity Capital Ratio } \\
\text { (DER) }\end{array}$} & Total Debt \\
\hline & Shareholders' Equity \\
\hline
\end{tabular}

Source : Subramanyam, 2014:560)

\section{Company Value}

Eugene F. Brigham and Joel F. Houston (2013:518) has defined that Corporate value which is the present value of expected free cash flow, discounted at a weighted average cost of capital. Referring to Sukamulja (2004, in Heder: 2017), one of the alternative way to evaluate the company value is by applying Tobin's $Q$. This ratio is developed by James Tobin, which is considered to be able to provide the best information about the phenomena of company's activities such as the connection between the managerial shareholder and the company value.

The company value can be measured by applying the ratio analysis approach based on the market value consisting of price earnings ratio (PER), price book value ratio (PBVR), market book ratio (MBR), dividend yield ratio, and dividend payout ratio (Brigham and Houston, 2013:150). This research has measured the company value using price book value ratio (PBV). This ratio measurement is important for the investors to define the strategy of portfolio at the capital market (Mayogi and Fidiana, 2016). PBV

Kamilah Sa'diah. The Effect of Corporate Financial Ratio upon The Company Value 
can be calculated based on the price of market shares against the book value of each share using the following equation:

$$
\text { PBV }=\frac{\text { Price Market per Share }}{\text { Book Value per Share }}
$$

Source: Brigham and Houston, 2013)

\section{Research Design}

Independent variable

Company Financial Ratio

1. Return On Assets

2. Dividend Payout Ratio

3. Debt-to Equity Ratio
Dependent Variable

\section{Company Value}

\section{Picture 1: Research Design}

\section{HIPOTESES}

$\mathrm{H} 1$ = Return on Assets has affected significantly the company value.

$\mathrm{H} 2=$ Dividend Payout Ratio has affected significantly the Company Value.

H3 = Debt-to Equity Ratio has affected significantly the Company Value.

\section{RESEARCH METHODOLOGY}

\section{Population and Sampling Procedure}

The population of this research is the companies indexed LQ-45 listed on the Indonesia Stock Exchange (BEI) year of 2015-2016. Sampling procedure has applied full sampling technics (Sugiyono, 2015:126), it is often being applied for relatively small population (all the members of a population are the samples)

\section{Operational Variable}

\section{Independent Variables}

\section{Return On Assets}

Return on Assets (ROA) variable is measured by comparing net profit after tax with all total assets owned by the company.

\section{Dividend Payout Ratio}

Dividend Payout Ratio (DPR) variable is measured by comparing the total of dividend payout with the net profit after tax and each one of them is measured against the total market shares.

\section{Debt-to Equity Ratio}

Debt-to Equity Ratio (DER) variable is measured by comparing the total of all liabilities with the shares owned by the company. 


\section{Dependent Variable}

\section{Company Value}

The company value (PBV) dependent variable has applied the price-to book value (PBV) approach. PBV can be calculated by comparing the price of market shares with the book value of each share.

\section{Analysis Method}

Data analysis method of this research has applied multiple regression analysis. In addition, the equation of the regression is as follows;

$$
Y=\beta_{0}+\beta_{1} R O A+\beta_{2} D P R+\beta_{3} D E R+\varepsilon
$$

$\begin{array}{lll}\text { Description } & \\ \text { PBV } & : \text { Company value } \\ \text { ROA } & : \text { Return On Assets } \\ \text { DPR } & : \text { Dividend Payout Ratio } \\ \text { DER } & : \text { Debt-to Equity Ratio } \\ \text { B }_{0} & : \text { Constant } \\ B_{1} \ldots B_{3} & : \text { Reggression Coefficient } \\ \varepsilon & : \text { Error }\end{array}$

\section{RESULT AND DESCRIPTION}

Based on the descriptive statistics of the variables being used in this research, it can be described as follows:

Table 1 Descriptive statistics of the research variables

Descriptive Statistics

\begin{tabular}{|l|r|r|r|r|r|}
\hline & \multicolumn{1}{|c|}{$\mathrm{N}$} & Minimum & Maximum & \multicolumn{1}{c|}{ Mean } & \multicolumn{1}{c|}{ Std. Deviation } \\
\hline Return On Assets & 80 &,- 0644 &, 3332 &, 070544 &, 0722982 \\
Dividend Payout Ratio & 80 &, 0000 & 1,9632 &, 294070 &, 3185260 \\
Debt-to Equity Ratio & 80 & $-2,1700$ & 6,7600 & 1,260825 & 1,5593757 \\
Price-to Book Value & 80 &,- 09 & 14,51 & 2,7540 & 2,71659 \\
Valid N (list wise) & 80 & & & & \\
\hline
\end{tabular}

Source: Output SPSS 22.00 (2018)

Scattering data of the Price-to Book Value $(\mathrm{Y})$ variable is to measure the company value having the average value of 2.7540 with minus minimum value of 0.09 and max.value of 14.51. PBV value of the companies as the samples is quite varied with the deviation standard of 2.71659, it has happened due to the variety data of the samples being studied is quite big (mean value compares with the value of standard deviation which is more than $30 \%$ ).

Scattering data of Return on Assets (X1) variable is having the average value of 0.070544 with the minus minimum value of 0.0644 and max.value of 0.3332 . ROA value of the samples is quite varied; however, it has indicated good ROA. The value of standard deviation is indicated 0.0722982; it has happened due to the varied data of the samples being studied is relatively good (deviation value is bigger than the average value)

Scattering data of Dividend Payout Ratio (X2) variable is having the average value of 0.294070 with the minus minimum value of 0.0000 and max. Value of 1.9632 . DPR

Kamilah Sa'diah. The Effect of Corporate Financial Ratio upon The Company Value 
value of the samples is quite varied which is started from the companies having the policy not to payout the dividend up to the companies which distribute the shares to the shareholders. The value of standard deviation is indicated 0.3185260 , it has happened due to the variation data of the samples being studied are very big (the value of deviation is bigger than the mean value).

Scattering data of Debt-to Equity Ratio (X3) variable is having the mean value of 1.260825 with the minus minimum value of 2.1700 and max. value of 6.7600 . DER value of the companies is quite varied with the standard deviation of 1.5593757, it has happened due to the varied data of the samples being studied is very big (mean value compares to the standard deviation value is bigger than $30 \%$ ).

\section{Classical Assumption Test}

\section{Normality Test}

Table 2. Result of Kolmogorov-Smirnov Test (90 Samples Data)

\begin{tabular}{|l|c|c|}
\hline & Kolmogorov Smirnov Z & Probabilitas Signifikansi \\
\hline Skor Score & 0,222 & 0,000 \\
\hline
\end{tabular}

Source. Result of data processing SPSS 22.00 (2018)

Result of Kolmogorov-Smirnov test on the variable of company value which is 90 samples having $p$ value $=0.000$, since $p$ value $<0.05$, Ho is rejected, it can be concluded that the data is not distributing normal and is not breaking the classic assumption. Detecting the outlier can be done by converting the value of the data into the standardized score (Z-score). Result of data screening has obtained 5 (five) codes of the emitent/companies which are indicated outlier, they are BBTN, BJBR, LPPF, SSMS and UNVR which are having the Z value bigger than score " 3 " (enclosures). Nevertheless, there are only 40 companies being studied during two(two) years period, but total data of the samples determined is 80 (eighty) data.

Table 3. Result of Kolmogorov-Smirnov Test ( 80 samples data)

\begin{tabular}{|l|c|c|}
\hline & Kolmogorov Smirnov Z & Probabilitas Signifikansi \\
\hline Skor & 0,093 & 0,084 \\
\hline
\end{tabular}

Source. Result of Data Processing SPSS 22.00 (2018)

\section{Heteroscedasticity}

Heteroscedasticity test result of regression analysis has applied park test with the residual $\left(\mathrm{U}^{2} \mathrm{i}\right)$ value of regression analysis upon the independent variables $(R O A$, DPR and DER) using the regression equation as follows;

$$
\operatorname{Ln} U^{2} i=\alpha+\beta \operatorname{LnXi}+v i
$$

Table 4. Result of Park Test

\begin{tabular}{|l|c|}
\hline \multicolumn{1}{|c|}{ Research Variables } & Sig.value \\
\hline Nilai Constant & 0,755 \\
Return On Assets & 0,996 \\
Dividend Payout Ratio & 0,520 \\
Debt-to Equity Ratio & 0,818 \\
\hline
\end{tabular}

Source. Result of Data Processing SPSS 22.00 (2018)

The test result above has indicated that the regression coefficient value of residual value $\left(\mathrm{U}^{2} \mathrm{i}\right)$ upon the independent variables (ROA, DPR and DER) is having

Kamilah Sa'diah. The Effect of Corporate Financial Ratio upon The Company Value 
sig.value of more than $(>) 0.05$, nevertheless, there is not any heteroscedasticity problem happened on the regression model.

\section{Multicolinearity Test}

Table 5. Result of Multicolinearity Test

\begin{tabular}{|l|c|c|}
\hline Variable Independen & Tolerance & VIF \\
\hline Return On Assets & 0,527 & 1,896 \\
Dividend Payout Ratio & 0,570 & 1,755 \\
Debt-to Equity Ratio & 0,898 & 1,114 \\
\hline
\end{tabular}

Source. Result of Data Processing SPSS 22.00 (2018)

Result of multicolinearity test has obtained the value of variance inflation factors (VIF) of each variable is less than 10 , and the tolerance value is bigger than 0.1 . Nevertheless, this regression model is not indicated the problem of multicolinearity among the independent variables.

\section{Autocorrelation Test}

Table 6 Result of Autocorrelation Test

\begin{tabular}{ccccc}
\hline & $\mathrm{d} \mathrm{L}$ & $\mathrm{du}$ & $4-\mathrm{du}$ & $\mathrm{dw}$ \\
\hline Skor & 1,560 & 1,715 & 2,285 & 1,752 \\
\hline
\end{tabular}

Source. Result of Data Processing SPSS 22.00(2018)

Result of autocorrelation test has indicated dw value of 1.752 based on SPSS 22.00 output. The value of $\mathrm{du}$ and $\mathrm{d} \mathrm{L}$ with $\mathrm{k}=3$, each value is 1.715 and 1.560 . Autocorrelation test has required that regression model should have been between the value of $d u \leq d w \leq(4-d u)$ and it has not indicated any autocorrelation happened. Since the value of $d w$ is on the interval of $1.715<1.752<2.285$, it cannot reject Ho. Nevertheless, the regression model is not indicating either negative of positive autocorrelation happened.

\section{Hypothesis Test}

\section{Determinant $\left(\mathbf{R}^{2}\right)$ Coefficient Test}

Table 7 Result of Determinant Coefficient Test

Model Summary

\begin{tabular}{|l|c|r|r|c|}
\hline Model & $\mathrm{R}$ & $\mathrm{R}$ Square & $\begin{array}{c}\text { Adjusted R } \\
\text { Square }\end{array}$ & $\begin{array}{c}\text { Std. Error of the } \\
\text { Estimate }\end{array}$ \\
\hline 1 &, $808^{\mathrm{a}}$ &, 653 &, 639 & 1,63188 \\
\hline
\end{tabular}

a. Predictors: (Constant), Debt-to Equity Ratio, Dividend Payout Ratio, Return On Assets

b. Dependent Variable: Price-to Book Value

Source: Output SPSS 22.00 (2018)

Result of determinant coefficient test has indicated $R$ value of 0.808 indicating that multiple regression between independent variables and dependent variable has been identifying the strongest effect (between $0.8-1$ ). Determinant coefficient test has applied the value of Adjusted $R^{2}$ which is indicated 0.639 or 63.9 percent demonstrating that the changing of company value variable can be explained by the independent variables consisting of return on assets, dividend payout ratio and debt-to equity ratio which is in this research model, however, the rest of $36.1 \%$ is described by

Kamilah Sa'diah. The Effect of Corporate Financial Ratio upon The Company Value 
other variables which are not being examined. The value of standard error of the estimate of 1.63188 is multiple standard error prediction, it has indicated regression model with the index of price-to book value (PBV) estimated will have better prediction of company value since its value is less $(<)$ than standard deviation of the dependent variable which is 2.71659 .

\section{F-test}

Table 8. Result of F-test

\begin{tabular}{|c|c|c|c|c|c|c|}
\hline \multicolumn{7}{|c|}{ ANOVA $^{a}$} \\
\hline \multicolumn{2}{|c|}{ Model } & $\begin{array}{l}\text { Sum of } \\
\text { Squares }\end{array}$ & df & Mean Square & $\mathrm{F}$ & Sig. \\
\hline & $\begin{array}{l}\text { Regressi } \\
\text { on }\end{array}$ & 380,617 & 3 & \multirow{3}{*}{$\begin{array}{r}126,872 \\
2,663\end{array}$} & \multirow[t]{3}{*}{$\begin{array}{r}47,64 \\
2\end{array}$} & \multirow[t]{3}{*}{, $000^{\mathrm{b}}$} \\
\hline & Residual & 202,391 & 76 & & & \\
\hline & Total & 583,008 & 79 & & & \\
\hline & $\begin{array}{l}\text { endent Vari } \\
\text { lictors: (Cor }\end{array}$ & $\begin{array}{l}\text { Price-to Book Val } \\
\text {, Debt-to Equity } \mathrm{F}\end{array}$ & & . & & \\
\hline Sour & Dutput SP & $.00(2018)$ & & & & \\
\hline
\end{tabular}

Based on the analysis of T-test or ANOVA, it is indicating p-value of 0.000 with its sig.value less than alpha $5 \%$, so that, the variable of company financial ratio consisting of return on assets, dividend payout ratio and debt-to equity ratio simultaneously has affected the company value.

\section{T-test}

Table 9 Result of t-test

Coefficients $^{\mathrm{a}}$

\begin{tabular}{|c|c|c|c|c|c|}
\hline \multirow[b]{2}{*}{ Model } & \multicolumn{2}{|c|}{$\begin{array}{l}\text { Unstandardized } \\
\text { Coefficients }\end{array}$} & \multirow{2}{*}{$\begin{array}{c}\text { Standardized } \\
\text { Coefficients } \\
\text { Beta }\end{array}$} & \multirow[b]{2}{*}{$t$} & \multirow[b]{2}{*}{ Sig. } \\
\hline & $\mathrm{B}$ & Std. Error & & & \\
\hline 1 (Constant) & 259 & ,331 & & ,784 & 435 \\
\hline Return On Assets & 25,129 & 3,497 & ,669 & 7,186 & ,000 \\
\hline $\begin{array}{l}\text { Dividend Payout } \\
\text { Ratio }\end{array}$ & 1,836 & ,764 & 215 & 2,404 & ,019 \\
\hline $\begin{array}{l}\text { Debt-to Equity } \\
\text { Ratio }\end{array}$ & 144 & , 124 & ,083 & 1,162 & 249 \\
\hline
\end{tabular}

a. Dependent Variable: Price-to Book Value

Source. Output SPSS 22.00 (2017)

$$
\mathrm{PBV}=0,259+25,129 \mathrm{ROA}+1,836 \mathrm{DPR}+0,144 \mathrm{DER}+\mathrm{è}
$$

Referring to the regression equation above, it has explained that variable of company value (PBV) has been affected by the independent variables of company finance ratio (return on assets, dividend payout ratio and debt-to equity ratio) as described on the following;

Constant

Return On Assets (ROA) is -1.024 , it means that if $m$ return on assets, dividend payout ratio and debt-to equity are constant, the company value will be 0.259 unit.

is having $\beta$ coefficient value of 25.129 . It means that if other independent variables are constant, and variable

Kamilah Sa'diah. The Effect of Corporate Financial Ratio upon The Company Value 
of return on asset is increased or increasing, the variable of company value will have an increasing of 25.129 .

Dividend Payout Ratio (DPR) is having $\beta$ coefficient value of 1.836 . It means that if other independent variables are constant, and dividend payout ratio variable is increased, company value will have an increasing of 1.836 .

Debt-to Equity Ratio (DER) is having $\beta$ coefficient value of 0.144 . It means that if other independent variables are constant and debt-to equity ratio variable is increased, company value will have no significant increasing of 0.144 .

\section{Description and Result of the Research}

Based on the result of hypothesis test of t-test on the table 9 , the proof of hypothesis about company financial ratio upon the company and description of the result and if it is evaluated by the result of previous research, will be as follows;

1. Result of the first hypothesis has indicated that variable return on assets (ROA) has affected significantly the company value variable due to its sig.level of 0.000 with coefficient value of 25.129 , it can be concluded that the hypothesis offered is in compliance with the research findings ( $\mathrm{H} 1$ is accepted). The higher value of return on assets (ROA) owned by the company and the related company has been able to book the profit which is continuously increasing will be indicating that the related company is having good performance measured by price-to book value (PBV), this condition has created positive signal for the investors. This findings complies with the research of Gayatri and Mustanda (2013), Hermuningsih (2013), Wahyuningsih (2015), Mayogi and Fidiana, (2016), Utomo (2016), Ayem and Nugroho (2016) and Astutik (2017) which have applied ROA ratio to measure its profitability. This condition is able to reduce the agency problems and as the basic evaluation and compensation payout of job contract in developing the company value thru return on assets (ROA)

2. Result of the second hypothesis test has indicated that dividend payout ratio (DPR) has affected significantly the variable of company value refer to its significant level of 0.019 with the coefficient value of 1.836 , it can be concluded that the hypothesis offered is in compliance with the findings of the research (H2 is accepted). The higher value of dividend payout ratio (DPR) declared by the company at that moment would maximize the price of company shares as well as create positive signal for the investors upon the amount of the dividend that will be received. This finding does not comply with the research of Gayatri and Mustanda (2013), Wahyuningsih (2015), Ayem and Nugroho (2016) which has not proven that the effect of dividend policy upon the company value has happened based on dividend payout ratio (DPR). The percentage of profit payout as dividend will be fluctuating from time to time along with the total of opportunity received by the company, it is in compliance with the signaling theory describing that higher dividend per share has indicated the company is sure that the expected cash flow will cover big level of dividend (Weston and Copeland, 2010). On the other words, the managers should have had definite certainty to payout the dividend as their responsibility over company value thru the increasing price of its shares accordingly.

3. Result of the third hypothesis test has indicated the variable of debt-to equity ratio (DER) has not affected significantly the variable of company value refers to its sig.level of 0.249 with the coefficient value of 0.144 , so that it can be concluded that the hypothesis offered is not complied with the research findings ( $\mathrm{H} 3$ is rejected). The higher value of debt-to equity ratio (DPR) owned by the company has indicated the ability of the company to pay the liabilities using the capital structure to maximize the company value. The findings of this research are not in compliance with the

Kamilah Sa'diah. The Effect of Corporate Financial Ratio upon The Company Value 
research of Gayatri and Mustanda (2013), Hermuningsih (2013), Ayem dan Nugroho (2016), Utomo (2016) which have not proved the effect of credit policy upon the company value is happened which is stipulated on debt-to equity ratio (DER) basis. Fluctuative credit has not affected the price of market shares, however, due to the market condition, the investors are not only concerned about the liabilities being used, but also they have the tendency to be concerned about how the managers have designed the credit policy effectively and efficiently to achieve best company value (Mayogi and Fidiana, 2016), however, it has been providing the positive signal for the investors and prospect investors to choose the alternative financing method which is from the third party (Astutik, 2017). This ratio has attracted the shareholders' intention to place their investment and at the end, it will affect the increasing price of the shares and company value obviously.

\section{CONCLUSION AND SUGGESTIONS}

\section{Conclusion}

Based on the result of the research and its description, this research can be concluded as the following

1. Return on Assets has affected significantly the company value.

2. Dividend Payout Ratio has affected significantly the company value.

3. Debt-to Equity Ratio has not affected significantly the company value.

\section{Suggestions}

1. For investors, this research is an important input to use the ROA, DPR and DER ratio approach to make decision whether to invest their capital specifically on the companies listed on BEI on the Index of LQ-45 (having active shares).

2. For the companies, this research has provided an important input for the companies to manage its resources efficiently and effectively using the price-to book value (PBV) approach which is at the end it will be increasing the company value.

3. For next researchers, this research is expected to provide a contribution upon the accountancy study about the investment decision thru the main financial ratio (ROA, DPR and DER) against the company value as the reference.

\section{ENCLOSURE}

\begin{tabular}{|c|c|c|c|c|}
\hline No. & $\begin{array}{c}\text { Emitent } \\
\text { Code }\end{array}$ & Year & $\begin{array}{l}\text { Outlier } \\
\text { Value }\end{array}$ & Variable \\
\hline 1 & BBTN & $\begin{array}{l}2016 \\
2015\end{array}$ & $\begin{array}{l}3,60528 \\
4,11399\end{array}$ & ZDER \\
\hline 2 & BJBR & $\begin{array}{l}2016 \\
2015 \\
\end{array}$ & $\begin{array}{l}3,09656 \\
3,43994\end{array}$ & ZDER \\
\hline 3 & LPPF & $\begin{array}{l}2016 \\
2015 \\
\end{array}$ & $\begin{array}{l}3,35593 \\
3,79324 \\
\end{array}$ & ZROA \\
\hline 4 & SSMS & $\begin{array}{l}2016 \\
2015\end{array}$ & $\begin{array}{l}-8,54308 \\
-0,30949 \\
\end{array}$ & ZDPR \\
\hline 5 & UNVR & $\begin{array}{l}2016 \\
2015 \\
\end{array}$ & $\begin{array}{l}3,02086 \\
2,92368\end{array}$ & ZROA \\
\hline
\end{tabular}

Kamilah Sa'diah. The Effect of Corporate Financial Ratio upon The Company Value 


\section{REFERENCES}

Ambarwati, SDA. (2010). Advanced Financial Management, Graha Ilmu, Jakarta.

Ang, R. (2010). Hand-book Capital Market in Indonesia, edition $7^{\text {th }}$, Mediasoft Indonesia, Jakarta.

Arshad, Z., Akram, Y., Amjad, M. and Usman, M. (2013). Ownership structure and dividend policy, accessed on March12, 2016. By <http://journalarchieves34.webs.com/378-401.pdf>

Astutik, D. (2017). The Effect of Ratio Finance Activities upon the Company Value. Jurnal STIE Semarang, 9 (1), pp 35-49.

Ayem, S. and Ragil Nugroho (2016). The effect of profitability, Capital Structure, Dividend Policy, and Investment Decision upon the Company Value, Periode 2010-2014. 4 (1), pp 31-39.

Blaylock, B., Shevlin, T., and Wilson, RJ. (2012) Tax Avoidance, Large Positive Temporary Book-Tax Differences, and Earnings Persistence. The Accounting Review, 87(1), pp 91-120.

Brigham, F. Eugene and Houston, Joel F. (2013). Fundamental of Financial Management $\left(13^{\text {th }} \mathrm{Ed}\right)$, South Western Cengage Learning.

Elinda, F. and Sukirman. (2015). Determinant Finance Ratio upon the Dividend Policy, Accounting Analysis Journal, 4 (4), pp 1-8.

Gayatri, NLPR, and Mustanda, IK. (2013). Effect of Capital Structure, Dividend Policy and Investment Decisions on Company Values, Faculty Economics and Business, Udayana University, pp 1700-1717.

Ghozali, I. (2017). Application of Multivariate Analysis using the Program IBM SPSS 23, Publisher of Diponogoro University, Semarang.

Hermuningsih, S. (2013). The Effect of Profitability, Growth Opportunity, Capital Structure upon the Company Value at the Public Companies in Indonesia, Bulletin Monetary Economics and Banking, pp 127-148.

Kasmir. (2012). Analysis of Finance Report, PT. Rajagrafindo Persada, Jakarta.

Mayogi, D.G. and Fidiana. (2016). The Effect of Profitability, Dividend Policy and Credit Policy upon the Company value, Jurnal IImu dan Riset Akuntansi, 5 (1), pp 118.

Melani, A. (2014). 5 Shares who's Prices are Upside Down, accessed on December 14, 2017 by <https://bisnis.liputan6.com/read/2062334/5-saham-yang-harganyajungkir-balik>

Rayanti, D. (2016). BI has developed again Index LQ45 Future, accessed on December 14,2017 by <https://finance.detik.com/bursa-valas/3131647/bei-kembalikembangkan-indeks-lq45-futures?f9911033=>.

Sartono, A. (2010). Finance Management, Theory and Application, $4^{\text {th }}$ ed, BPFE, Yogyakarta.

Sugiyono. (2015). Mixed Methods Research Seventh printed, CV. Alfabeta, Bandung.

Kamilah Sa'diah. The Effect of Corporate Financial Ratio upon The Company Value 
Utomo, N.A. (2016). Factors affecting the company value at the companies having LQ45 index at Indonesia Stock Exchange, Dinamika Akuntansi, Keuangan dan Perbankan. 5(1), pp 82-94.

Wahyuningsih, D. (2015). The Effect of Managerial Ownership, Institutional Ownership, Dividend Policy, Credit Policy and Proft Management upon the Company Value, University of Muhammadiyah Surakarta, Surakarta.

Weston, Fred, J. and Thomas, E Copeland. (2010). Finance Management, Binarupa Aksara Publisher, Jakarta.

Kamilah Sa'diah. The Effect of Corporate Financial Ratio upon The Company Value 
The Accounting Journal of BINANIAGA Vol. 03, No. 02, December 2018

PISSN: $2527-4309$

EISSN: $2580-1481$

This page intentionally be emptied.

Kamilah Sa'diah. The Effect of Corporate Financial Ratio upon The Company Value 